\title{
Spatial Variation in Remnant Grasses After a Grassland-to-Shrubland State Change: Implications for Restoration
}

\author{
Debra P. C. Peters, ${ }^{1}$ Isabella Mariotto, ${ }^{2}$ Kris M. Havstad, ${ }^{3}$ and Leigh W. Murray ${ }^{4}$ \\ Authors are ${ }^{1}$ Rangeland Scientist, ${ }^{2}$ Research Associate, and ${ }^{3}$ Supervisory Rangeland Scientist, \\ US Department of Agriculture-Agricultural Research Service, Jornada Experimental Range, \\ New Mexico State University, Las Cruces, NM 88003; and ${ }^{4}$ Professor, University Statistics Center, \\ New Mexico State University, Las Cruces, NM 88003.
}

\begin{abstract}
Around the world rangelands that have been degraded, such as historical desert grasslands now dominated by woody shrubs, are resistant to restoration efforts. The goal of this descriptive research was to examine the potential for black grama (Bouteloua eriopoda [Torr.] Torr.) recovery by remnant plants in a degraded area as a function of plant location across a landscape. Our objectives were 1) to document the historical dominant vegetation as a perennial grassland and determine broad-scale changes in dominance through time and 2) to examine fine-scale patterns of black grama presence and basal area with respect to microenvironmental conditions that indicate the landscape positions favorable for restoration. Historical vegetation maps starting in 1858, a field survey in 2002-2003 of the location of all individual black grama plants in a 29-ha area, and spatial data layers in a geographic information system were used to address these objectives. Upland grasses, including black grama, dominated the study site in 1858, although tarbush (Flourensia cernua DC.) was the dominant species by 1915, and creosotebush (Larrea tridentata [DC.] Cov.) is the current dominant. A total of 3334 black grama plants were found for an average density of 0.01 plants $\cdot \mathrm{m}^{-2}$. High spatial variation was found in the occurrence and basal area of black grama plants that was related to water availability rather than livestock grazing: most plants were found in or adjacent to an arroyo (67\%), at a northern aspect $(47 \%)$, and outside experimental exclosures established in $1930(43 \%)$. Largest average basal areas were found in the livestock exclosure, and in general, average basal area was not related with aspect or canopy microsite. These remnant plants can be used as propagule sources in restoration efforts, and information on microsite conditions for black grama survival can be used to improve restoration potential for similar sites.
\end{abstract}

\section{Resumen}

Al rededor del mundo los pastizales que han sido degradados, tal como los históricos pastizales desérticos actualmente dominados por arbustos leñosos, son resistentes a las acciones de restauración. La meta de esta investigación descriptiva fue examinar el potencial del "Black grama" (Bouteloua eriopoda [Torr.] Torr.) para recuperarse a partir de plantas remanentes en áreas degradadas en función de la localización de la plantas a través del paisaje. Nuestros objetivos fueron: 1) Documentar la vegetación dominante histórica como pastizal perenne y determinar los cambios a gran escala en la dominancia a través del tiempo; 2) Examinar los patrones, a escala fina, de la presencia del "Black grama" y el área basal con respecto a las condiciones microambientales que indiquen posiciones favorables del paisaje para la restauración. Para lograr los objetivos se usaron mapas históricos de vegetación desde 1858, un muestro de campo de 2002-2003 de la localización de todas las plantas individuales de "Black grama" en un área de 29 ha y capas de datos espaciales de sistemas de información geográfica. Los zacates de terrenos altos, incluyendo "Black grama", dominaron el área de estudio en 1858, aunque para 1915 el "Tarbush" (Flourensia cernua DC.) fue la especie dominante y el "Creosotebush" (Larrea tridentata [DC.] Cov.) es la especie actualmente dominante. Un total de 3334 plantas de "Black grama" fueron encontradas equivalente a una densidad promedio de 0.01 plantas $/ \mathrm{m}^{2}$. Se encontró una alta variación espacial en la ocurrencia y área basal de las plantas de "Black grama", que estuvo correlacionada con la disponibilidad de agua mas que con el apacentamiento del ganado: la mayoría de las plantas fueron encontradas dentro o adyacentes a un arroyo (67\%), en la exposición norte $(47 \%)$ y fuera de las exclusiones experimentales establecidas en 1930 $(43 \%)$. El mayor promedio de áreas basales fueron encontradas en la exclusión al ganado, y en general , el área basal promedio no estuvo correlacionada con la exposición o la cobertura del micrositio. Estas plantas remanentes pueden ser usadas como fuentes de propágulos en los acciones de restauración y la información de las condiciones del micrositio puede ser usadas para mejorar el potencial de restauración del "Black grama" en sitios similares.

Key Words: Bouteloua eriopoda, Larrea tridentata, Flourensia cernua, perennial grasslands, shrub invasion

Research was conducted by the US Dept of Agriculture-Agricultural Research Service Jornada Experimental Range and the Jornada Basin Long-Term Ecological Program funded by the National Science Foundation (DEB 0080412).

Correspondence: Debra Peters, US Dept of Agriculture-Agricultural Research Service, Jornada Experimental Range, Box 30003, MSC 3JER, NMSU, Las Cruces, NM 88003-0003. Email: debpeter@nmsu.edu

Manuscript received 19 November 2005; manuscript accepted 26 April 2006.

\section{INTRODUCTION}

Changes in dominance from one lifeform to another have occurred in many terrestrial systems with important consequences for changes in biodiversity, primary and secondary productivity, carbon and nitrogen dynamics, and soil properties 
(e.g., Gibbens et al. 1983; Archer et al. 1988; Archer 1989; Warren et al. 1996; Ricketts et al. 1999; Gillette and Chen 2001). In many cases, these altered sites have resulted in state changes that are difficult to restore or revegetate because of modifications to surface soil properties, such as the amount and distribution of resources and soil organic matter, and the limited availability of propagules from the previous community (Schlesinger et al. 1990; Archer 1994; Whisenant 1999; Peters 2002).

State changes in life-form dominance may occur at a broad scale, but variation in changes from one state to another also occurs at finer scales, such as within an ecological site or landscape unit (Peters et al. 2006). Although a community may be dominated by a new life-form, remnant plants from the previous community may still persist. If these remnant plants occur, then they would provide propagules for recovery as well as indicate microsite requirements for establishment and survival under the modified environmental conditions. Little information is known about remnant plants in degraded, statealtered communities.

It is well-documented that in the Chihuahuan Desert of North America, large areas of perennial grassland have converted to shrub-dominated communities over the past 100 to 150 years (Buffington and Herbel 1965; York and Dick-Peddie 1969; Grover and Musick 1990). Similar to other arid and semiarid areas, attempts to restore grasses to these areas have often failed or have had limited success after long time lags (Rango et al. 2002; Herrick et al. 2006). Most attempts have involved either reseeding of perennial grasses following shrub removal (with or without additional water or nutrients) (Ethridge et al. 1997) or the manipulation of water to increase local run-on to existing patches of grasses (Herrick et al. 2006). The presence and abundance of remnant grass species that previously dominated the community and are available for restoration efforts are typically unknown.

At the Jornada Experimental Range in southern New Mexico, a long-term restoration study was conducted by constructing a livestock and lagomorph exclosure in a creosotebush-dominated bajada in the 1930s; shrubs have been removed periodically through time and sampling of vegetation continues to the present (Gibbens et al. 1993). The study showed very slow recovery of black grama (Bouteloua eriopoda [Torr.] Torr.), an important dominant species on upland communities; by 1995 , average black grama cover was still $<2 \%$ (Havstad et al. 1999). Our goal was to determine the potential for black grama recovery by remnant plants in the exclosure and in the surrounding grazed area in order to explain this very slow recovery.

We hypothesized that the spatial distribution of black grama plants is related to physical characteristics of the site that influence fine-scale patterns in water availability rather than effects of livestock and lagomorph exclusion and shrub removal. A livestock exclosure allowing lagomorphs and containing shrubs at natural levels located adjacent to the treatment exclosure provided for an analysis of the effects of livestock exclusion only on patterns in black grama. We had 2 specific objectives: 1 ) to document that the historic dominant vegetation included black grama, and to determine changes in broad-scale dominance through time for this area, and 2) to examine current fine-scale patterns of black grama with respect to microsite environmental conditions for 3 locations (shrub removal-livestock exclosure, livestock exclosure, grazed area) that indicate landscape positions favorable for restoration.

\section{MATERIALS AND METHODS}

\section{Study Site}

The study site is located at the Jornada Experimental Range in southern New Mexico, USA (lat $32^{\circ} 30^{\prime} \mathrm{N}$, long $106^{\circ} 48^{\prime} \mathrm{W}$ ) on a west-facing bajada slope of the San Andres Mountains. Elevation ranges from 1480 to $1500 \mathrm{~m}$, and the long-term average precipitation (1923-2003) at the nearest rain gauge (1 $700 \mathrm{~m}$ away) is $259 \mathrm{~mm} \cdot \mathrm{y}^{-1}$. Precipitation during the time of the study (2002-2003) was below average $\left(191 \mathrm{~mm} \cdot \mathrm{y}^{-1}\right)$. Soils belong to the Typic Paleorthid family (Tencee series, gravelly loamy sand) formed on an old alluvial fan. This is a gravelly loam ecological site (ID number R042XB035NM) within the Southern Desertic Basins, Plains, and Mountains major land resource area (MLRA number 42). Broad-scale characteristics include a $2 \%$ to $6 \%$ slope with a series of small arroyos that bisect the area and flow generally east to west from the mountains to the basin floor.

The study site is a 530- $\times 550-\mathrm{m}$ area $(29$ ha) centered on a $167-\times 150-\mathrm{m}(2.5 \mathrm{ha})$ exclosure constructed for livestock and lagomorph exclusion and shrub removal in the 1930 s (hereafter referred to as the "shrub removal-livestock exclosure"). The site includes part (7.7 ha) of an adjacent 260 -ha exclosure constructed for livestock exclusion at the same time period ("livestock exclosure"). The remaining area (18.8 ha) has been grazed by cattle since the mid-1800s without shrub removal treatments ("grazed area"). Vegetation cover in the study site is currently dominated by the native shrub, creosotebush (Larrea tridentata [DC.] Cov.) with an average of 13\% cover (Gibbens et al. 1993). Other shrubs, in particular honey mesquite (Prosopis glandulosa Torr.) and tarbush (Flourensia cernua DC.), and forbs average 10\% cover. Perennial grasses, including bush muhly (Mublenbergia porteri Scrib. ex Beal) and spike dropseed (Sporobolus contractus Hitchc.) average $4 \%$ cover, with $<2 \%$ cover attributed to black grama (Gibbens et al. 1993; Havstad et al. 1999).

\section{Historic Vegetation and Broad-Scale Changes in Dominance Through Time}

A vegetation map from 1858 reconstructed from land survey records was used to determine the historic vegetation of the study site (Buffington and Herbel 1965). Because the original map used broad classes describing the abundance of grasses (very good, good, fair, poor) and shrub presence or absence, we used vegetation maps from 1915 and 1928-1929 (Gibbens et al. 2005 ) to determine the identity and location of uplands or playa grasses or, in some cases, the grass species (burrograss, Schleropogopon brevifolius Phil.) with a distinctive location that did not change between 1915 and 1928-1929. We also used the 1915 and 1998 vegetation maps from Gibbens et al. (2005) as indicators of changes in vegetation through time. Because the area surveyed in this study ( $29 \mathrm{ha}$ ) was small relative to the resolution of the historical vegetation maps, all of the study site was mapped as 1 vegetation type in each survey year. Thus, only broad-scale patterns in species dominance can be observed. 


\section{Current Fine-Scale Patterns of Black Grama Plants}

Fine-scale patterns in black grama plants were examined using a field survey and layers in a spatial database. The 3 locations in the 29-ha study site (shrub removal-livestock exclosure, livestock exclosure, grazed area) were surveyed for all black grama plants between October 2002 and August 2003. Location of each plant was determined using a submeter accuracy Trimble geopositioning station (GPS) unit. Two diameters were measured for each black grama plant to estimate basal area assuming an ellipsoid shape. Three environmental factors that were expected to influence fine-scale patterns in water availability (aspect, position from nearest shrub canopy, and distance to the nearest arroyo) were characterized for each plant. Aspect (north, east and west, south) and position within a shrub canopy (inside cresosotebush, inside other plants, outside plants) were determined in the field. Distance to the nearest arroyo from each plant was calculated using a 2001 US Geological Survey color infrared digital orthophotoquad (DOQ) at a scale of 1:24 000 and a 1-m pixel resolution. Each arroyo was screen digitized from the DOQ and corrected using field observations. The GPS location of each black grama plant was overlaid on the arroyo map, and distance was calculated using 4 distance classes $(0 \mathrm{~m}=$ inside an arroyo, $0 \mathrm{~m}<$ distance $\leq 2 \mathrm{~m}, 2 \mathrm{~m}<$ distance $\leq 5 \mathrm{~m}$, and distance $>5 \mathrm{~m})$.

We also generated an equal number of randomly located points to compare microsite conditions without black grama plants with the conditions associated with black grama plants. These points were objectively selected using a uniform distribution in ArcView. For each random point, aspect was determined from a 2-m-resolution digital elevation model (http:// jornada-www.nmsu.edu/); distance from the nearest arroyo and the location (shrub removal-livestock exclosure, livestock exclosure, grazed area) were determined from the DOQ. Because we could not determine the position of a random point inside or outside a shrub canopy from the DOQ, and the resolution of the DOQ precluded the accurate location of each random point in the field relative to shrub canopy position, this factor was excluded from the random point characterization and analysis.

\section{Statistical Analyses of Fine-Scale Patterns}

Two sets of statistical analyses were conducted to relate black grama plants to microenvironmental conditions and to identify the landscape positions favorable for restoration. The first set examined the probability that a black grama plant would be found in different microsites (aspect, distance to the nearest arroyo) for each of 3 locations (shrub removal-livestock exclosure, livestock exclosure, grazed area), and if these probabilities are significantly different from the random points without black grama plants. The second set examined the relationship between black grama basal area for different microsites including canopy position within each location.

Presence-Absence. Logistic analysis of variance (ANOVA) models were used to determine the probability of the presence of a black grama plant for each aspect and distance to the nearest arroyo for each location. Because the distance from a plant to the nearest arroyo was always greater than $5 \mathrm{~m}$ in the shrub removal-livestock exclosure, 2 analyses were conducted.
The first analysis compared the probability of plant presence for all 3 locations and 3 aspects, but only for those plants located at distances greater than $5 \mathrm{~m}$ from an arroyo. The second analysis compared the probability of plant presence in the grazed area with the probability inside the livestock exclosure for all 3 aspects and 4 distances.

Basal Area. Because black grama basal area data were highly (positively) skewed, an ANOVA generalized linear model with a gamma distribution was used to examine the relationship between basal area of each black grama plant and the same 2 factors as above, as well as position with respect to a shrub canopy. Analyses were conducted separately for the 3 locations as a result of limitations in the data. Because distance to the nearest arroyo was always more than $5 \mathrm{~m}$ for the shrub removal-livestock exclosure location, the analysis for this location was a 3 (aspect) by 3 (canopy) factorial. For plants in the livestock exclosure, the treatment structure was a 3 (aspect) by 3 (canopy) by 4 (distance) factorial. For plants in the grazed area, data were sparse for the third distance category (2.1-5 $\mathrm{m}$ from an arroyo); thus the $0.1-$ to $2-\mathrm{m}$ and 2.1- to 5-m distance categories were pooled to result in a 3 (aspect) by 3 (canopy) by 3 (distance) factorial.

For all analyses, main effects and interactions were tested by likelihood ratio $\chi^{2}$ statistics with a significance level of $\alpha=0.05$. Least square means and standard errors either for the probability of the presence of a black grama plant or for basal area were calculated for the main effect and interaction combinations using the "delta rule" (Littell et al. 2002). Analyses were performed using SAS Proc Genmod (SAS $^{\circledR}$ Institute 1999), with either a binomial (plant presence) or gamma distribution (basal area).

\section{RESULTS}

\section{Historic Vegetation and Changes in Dominance Through Time}

Vegetation of the study site and the surrounding area changed from a grassland to a shrubland between 1858 and 1915 with subsequent changes in shrub species dominance until 1998 (Fig. $1)$. In 1858 , the study site was dominated by upland grasses, most likely black grama, bush muhly, and spike dropseed (Fig. 1a); these species dominated similar bajada locations at the Jornada in the early 1900s (Nelson 1934). By 1915, most of the study site was dominated by the shrub, tarbush (Fig. 1b), although photos from this time period show that some perennial grasses remained in shrub canopies and in interspaces between shrubs. By 1998, most of the study site was dominated by creosotebush with honey mesquite as the subdominant species (Fig. 1c).

\section{Presence of Black Grama Plants and Microenvironmental Conditions}

A total of 3334 black grama plants was found in 2002-2003 within the 29-ha area for an average density of 0.01 plants $\cdot \mathrm{m}^{-2}$. The location of plants was highly variable spatially (Fig. 2a) with most plants occurring in the grazed area $(n=1417)$ and the livestock exclosure $(n=1262)$ with the fewest plants found in the shrub removal-livestock 
(a) 1858

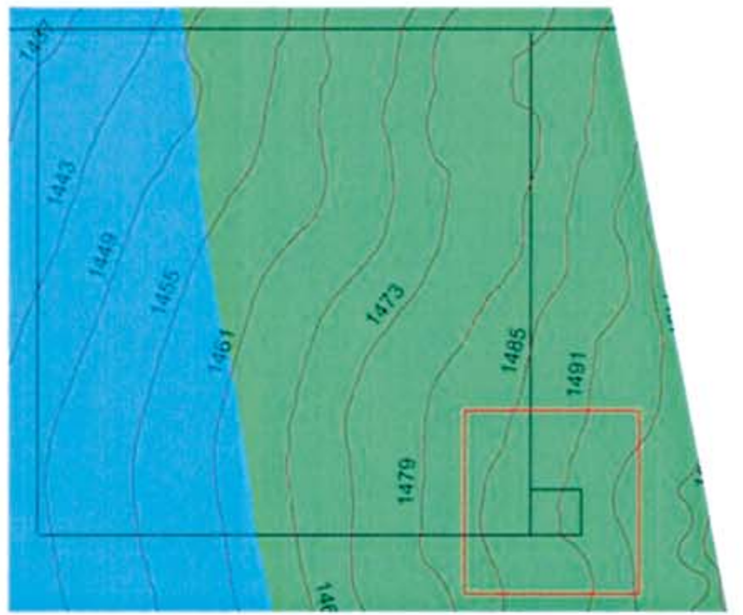

Playa grasses

Upland grasses

(b) 1915

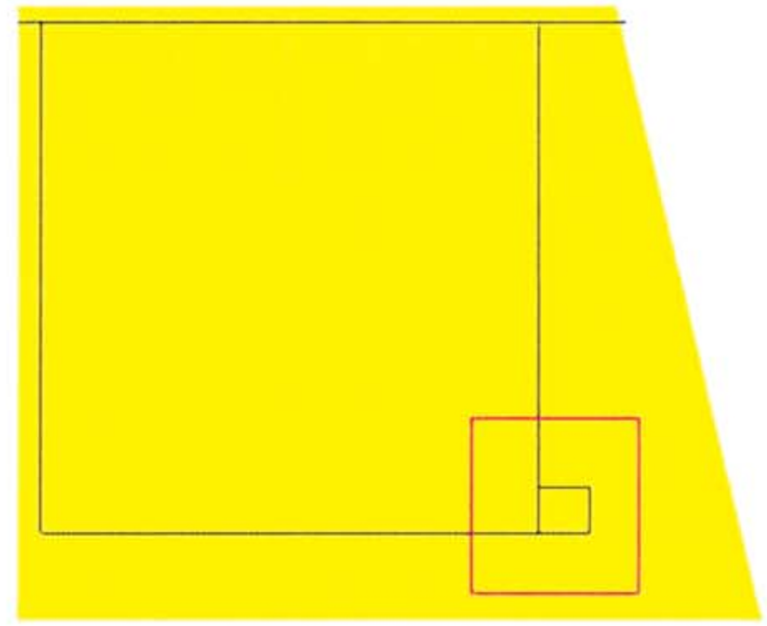

(c) 1998

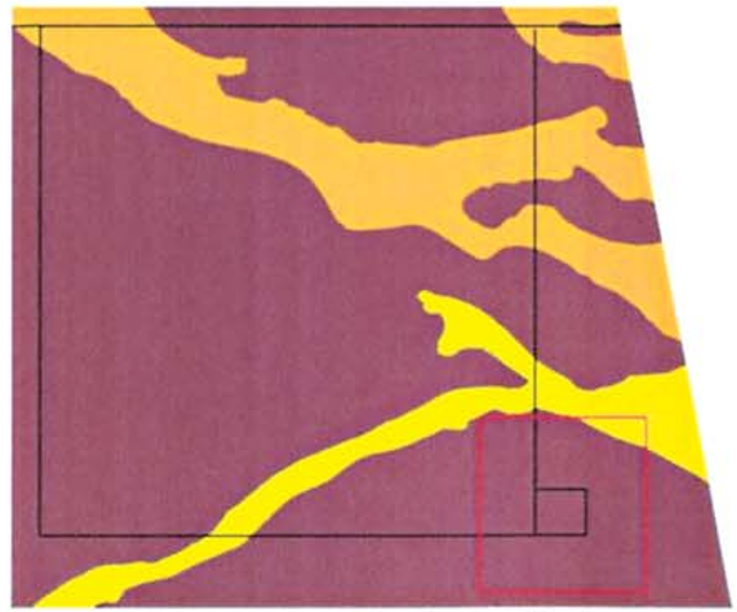

creosotebush, mesquite tarbush, creosotebush creosotebush, tarbush
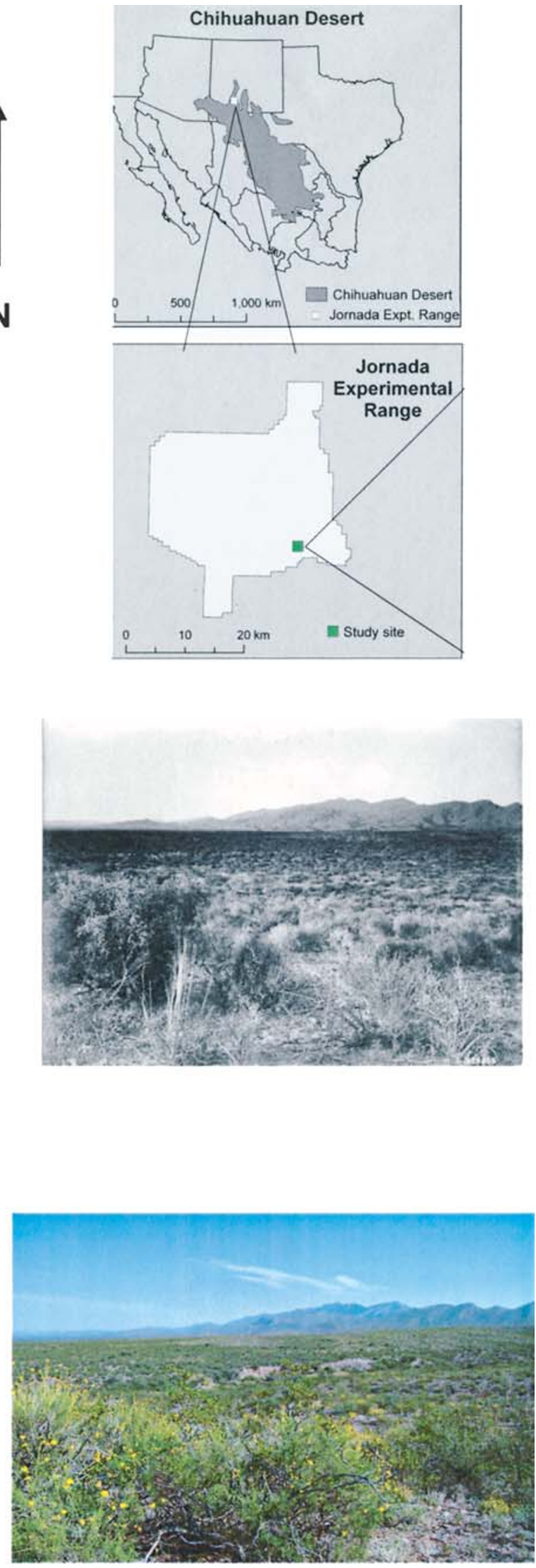
(a)

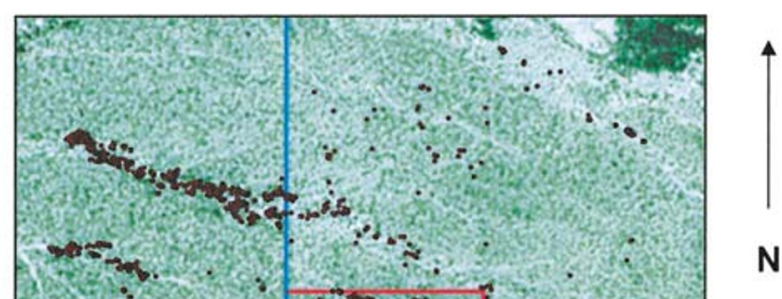

(b)

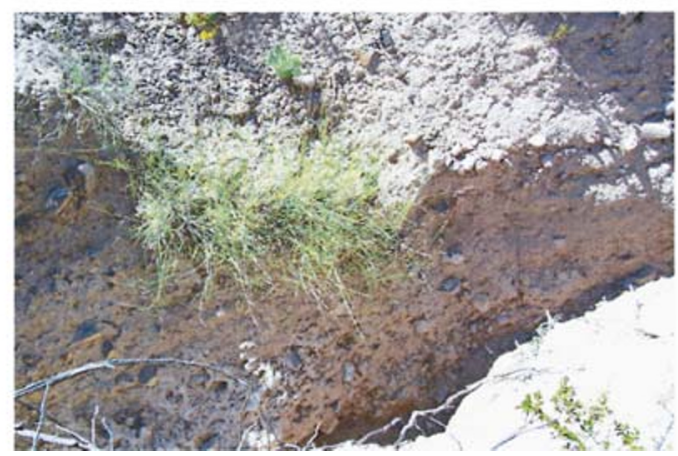

Figure 2. a, Location of the 3334 black grama plants in the 29-ha study area that includes 2 exclosures constructed in the 1930s (shrub removal-livestock exclosure, livestock exclosure) and the grazed area. b, Photo showing a black grama plant on the edge of an arroyo at a northern aspect and outside a shrub canopy in September 2005.

exclosure $(\mathrm{n}=655)$. Most plants were found inside or adjacent to arroyos $(67 \%)$, at a northern aspect $(47 \%)$, and located outside the exclosures (43\%) (Fig. 2b). Based on the logistic analysis, if a black grama plant was found, then there was a predicted $95 \%( \pm 1.7 \%)$ chance that it was located inside an arroyo, on a northern aspect, and outside both exclosures. This microsite characterization is significantly different from what was expected based on microsites of the random points.

Northern aspects had the highest predicted probabilities of black grama presence for distances $>5 \mathrm{~m}$ from an arroyo for
Distances $>5 \mathrm{~m}$

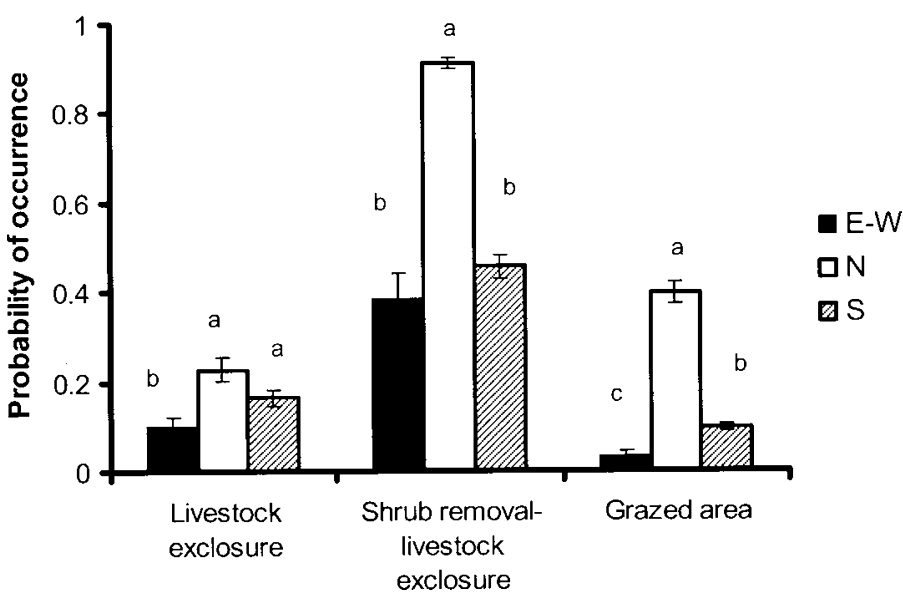

Figure 3. Predicted probability of black grama occurrence and standard deviation for 3 aspects within 3 locations for distances greater than $5 \mathrm{~m}$.

each location (Fig. 3). For these distances, highest average probabilities of occurrence were predicted in the shrub removal-livestock exclosure for all 3 aspects. For both locations where distance from the nearest arroyo was analyzed (livestock exclosure, grazed area), predicted probabilities decreased as distance increased, and lowest probabilities were predicted for plants on east-west aspects even though the broad-scale aspect is west-facing (Figs. $4 \mathrm{a}$ and $4 \mathrm{~b}$ ).

\section{Basal Area of Black Grama Plants and Microenvironmental Conditions}

For all 3 locations, most plants $(>90 \%)$ were small $(<1000$ $\mathrm{cm}^{2}$ basal area) (Fig. 5); the largest plant was ca. $8000 \mathrm{~cm}^{2}$. Larger average basal areas per plant were found in the livestock exclosure $\left(241.3 \mathrm{~cm}^{2}\right)$ compared with the shrub removal-livestock exclosure $\left(142.5 \mathrm{~cm}^{2}\right)$ and the grazed area $\left(128.1 \mathrm{~cm}^{2}\right)$. In general, basal area was not related to aspect or canopy microsite (Fig. 6). Microsite position was only important for east-west aspects for plants in the livestock exclosure and for south aspects in the grazed areas where largest plants were found outside shrub canopies. In the shrub removal-livestock exclosure, largest average basal areas were found on north aspects $\left(145.2 \mathrm{~cm}^{2}\right)$ compared with averages of $72.3 \mathrm{~cm}^{2}$ (eastwest) and $79.4 \mathrm{~cm}^{2}$ (south) (not shown). Distance from the nearest arroyo was not significant in these analyses.

\section{DISCUSSION}

State changes from perennial grasslands to shrub-dominated systems have occurred frequently throughout arid and semiarid

Figure 1. Vegetation of the study site through time and location of the study site within the Jornada Experimental Range: a, 1858 map from Buffington and Herbal (1965) and the location of the study site within the Jornada Experimental Range in 1858; topography lines are also shown; b, 1915 map from Gibbens et al. (2005) and photo from 1912 showing tarbush in the foreground where the study site is located and creosotebush in the background; and c, 1998 map from Gibbens et al. (2005) and photo taken in September 2005 from a similar location as the photo from 1912 showing creosotebush in the foreground and background. 
(a) Livestock exclosure

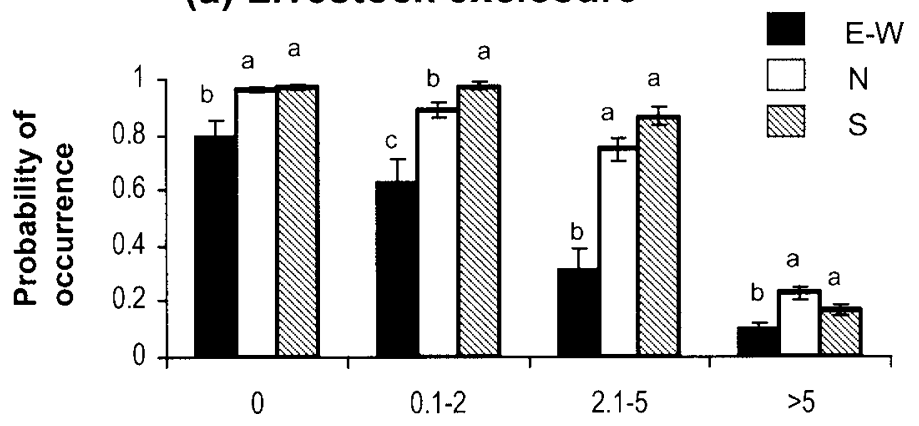

(b) Grazed area

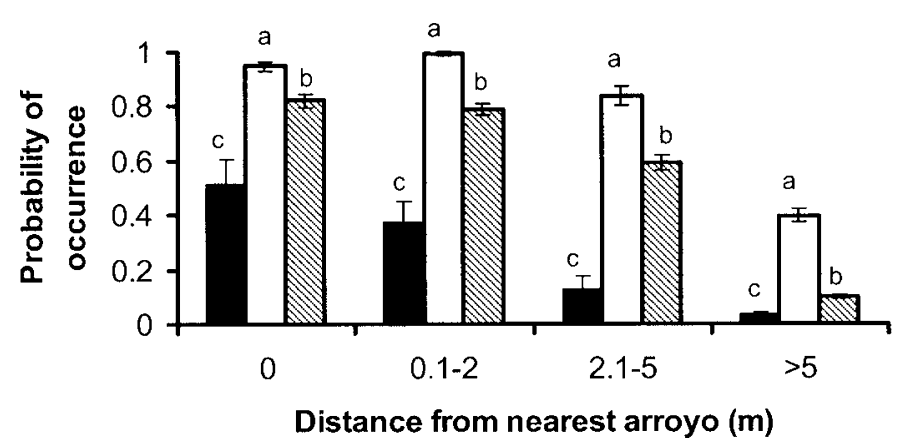

Figure 4. Predicted probability of occurrence of black grama and standard deviation for 3 aspects and 4 distances for plants in 2 locations: a, livestock exclosure and $\mathbf{b}$, the grazed area.

regions in North America and globally. Although most studies have focused on broad-scale changes from grass to shrub dominance, our results show that fine-scale patterns in plants of the historic dominant grass can occur within a shrubdominated matrix. For black grama, the very high probability $(0.95)$ that if a plant is found, then it occurs inside or adjacent to an arroyo, at a northern aspect, and outside long-term livestock exclosures can be used to identify and target potential microsites for successful restoration efforts in similar areas. These grass plants can be important as propagule sources for grass plant and population expansion.

Although the current community of our study site is overwhelmingly dominated by shrubs with $>82 \%$ of total vegetative cover, 150 years ago the area was dominated by upland grasses that likely included black grama, similar to other bajadas at the Jornada (Nelson 1934). Within a 60-year time period, the area shifted to a shrubland dominated by tarbush that may have included some creosotebush; this time period corresponds to peak numbers of cattle in the area during the "cattle boom" of the 1880s and extended severe droughts (Fredrickson et al. 1998). Within another 80 years, from 1915 to 1998 , another shift occurred to the current creosotebushdominated system, although tarbush plants still occur as subdominants. Factors that promote conversion from tarbush to creosotebush dominance are poorly understood. These conversions are likely to be only partly explained by the approximately 10 -fold decrease in animal units (primarily cattle) per (a) Shrub removal - Livestock exclosure

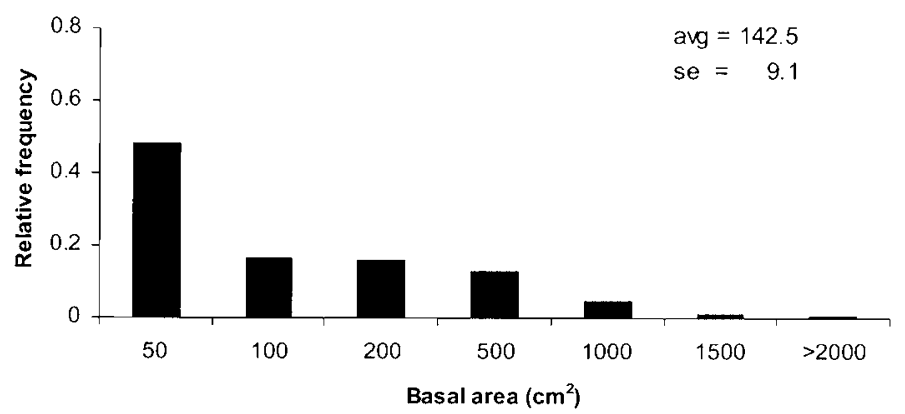

(b) Livestock exclosure

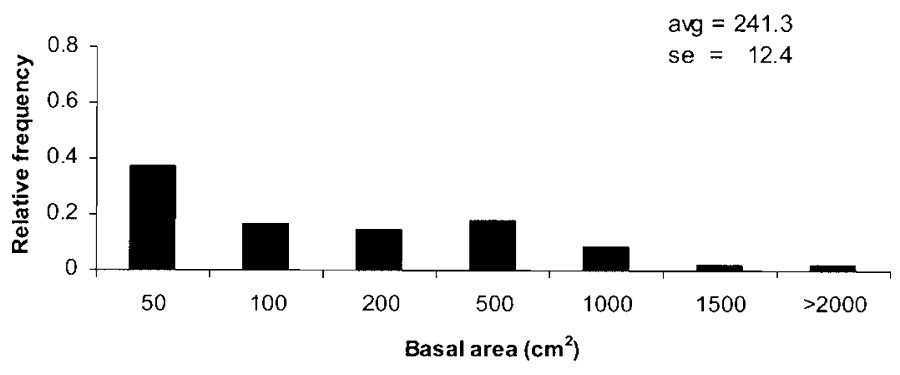

(c) Grazed area

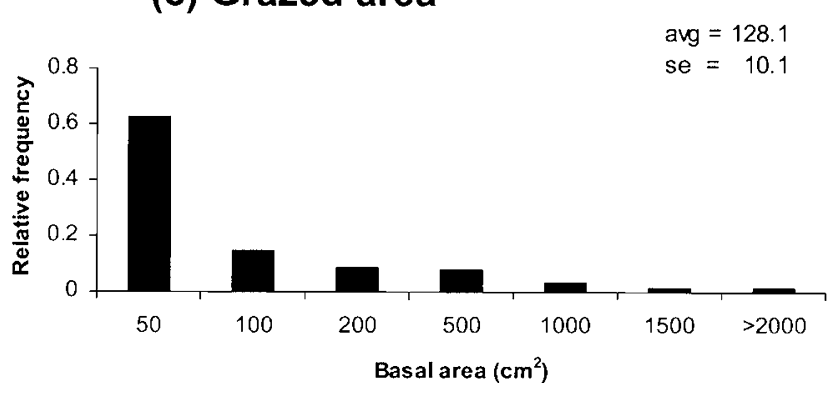

Figure 5. Frequency distribution of the basal area of black grama plants relative to the total number of plants for 3 locations: a, shrub removallivestock exclosure, b, livestock exclosure, and c, grazed area.

year across the Jornada Experimental Range during this time period (Fredrickson et al. 1998).

Our ability to find black grama plants within a shrub matrix in an area that was historically perennial grassland suggests that these plants are remnants or progeny from the original grass population rather than recent recruits from other areas. The dispersal of viable seeds of black grama from an adjacent source population is unlikely: the nearest large, contiguous population of black grama is located $>10 \mathrm{~km}$ east of the study site in the foothills of the San Andres Mountains. Black grama is primarily wind dispersed and the prevailing winds are from the west-southwest, thus dispersal of seeds would more likely occur from the west where a contiguous population of black grama plants does not exist within $15 \mathrm{~km}$ of the study site. In addition, black grama plants rarely produce viable seeds with infrequent seedling establishment events under current soil and 
climate conditions at the Jornada (Nelson 1934; Neilson 1986; Minnick and Coffin 1998).

The prevalence of black grama plants outside the exclosures indicates that livestock grazing, a continued dormant season practice in recent decades, is not limiting the current distribution of these plants. However, the larger average basal areas found within the livestock exclosure compared with the grazed area indicates the important effects of cattle grazing and trampling to black grama plant size, as found in other studies (Nelson 1934; Gadzia 1979). Livestock impacts are expected to be more important for establishing seedlings that are particularly susceptible to grazing and trampling; however, this study only examined adult plants. In addition, measured basal areas may have been smaller than long-term averages because our study was conducted during a period of below-average precipitation.

The overall low average density of black grama plants $(0.01$ plants $\cdot \mathrm{m}^{-2}$ ) suggests one explanation for the previously documented very slow recovery by black grama within the livestock exclosure with experimentally reduced shrub densities (Gibbens et al. 1993; Havstad et al. 1999). However, this low black grama density does not reflect the high spatial variation in plant presence. The combination of microsite conditions where most black grama plants are found (northern aspect, near an arroyo, and outside the exclosures) suggests that the current distribution of this species on creosotebush-dominated bajadas is limited by water availability and substrate. Microsites within arroyos receive additional water during storms that generate water runoff (Wainwright et al. 2002). Northern aspects are often cooler with lower evaporation rates during the summer growing season compared with other exposures, in particular southern aspects (Snyder et al. 2006). Large basal areas of black grama at northern aspects and outside shrub canopies support these findings. More accurate measurements of plants and microsites are needed to examine differences between the bottoms of arroyos that receive more frequent run-on than the sides of arroyos.

\section{MANAGEMENT IMPLICATIONS}

The history of efforts to revegetate degraded grasslands now dominated by woody species in arid rangelands is replete with failures (Ethridge et al. 1997; Herrick et al. 1997; Rango et al. 2002.). Our research suggests 3 important considerations in managing for revegetation of prior grasses in degraded southwestern rangelands. First, given inherent spatial heterogeneity, there are likely to exist small areas (microsites) within a pasture or allotment where reestablishment is more likely to succeed. For black grama in the northern Chihuahuan Desert on gravelly ecological sites, these microsites are north-facing slopes within arroyos. These sites should be the first priority for application of revegetation practices. Second, any success will require a long-term planning and implementation framework that includes both the expansion of existing plants and reseeding of new individuals. Third, although state changes are most obvious at broad spatial scales, fine-scale patterns at the scale of individual plants can be quite heterogeneous within these broad-scale changes. Spatial patterns at multiple scales need to be recognized and utilized in restoration studies. (a) Livestock exclosure
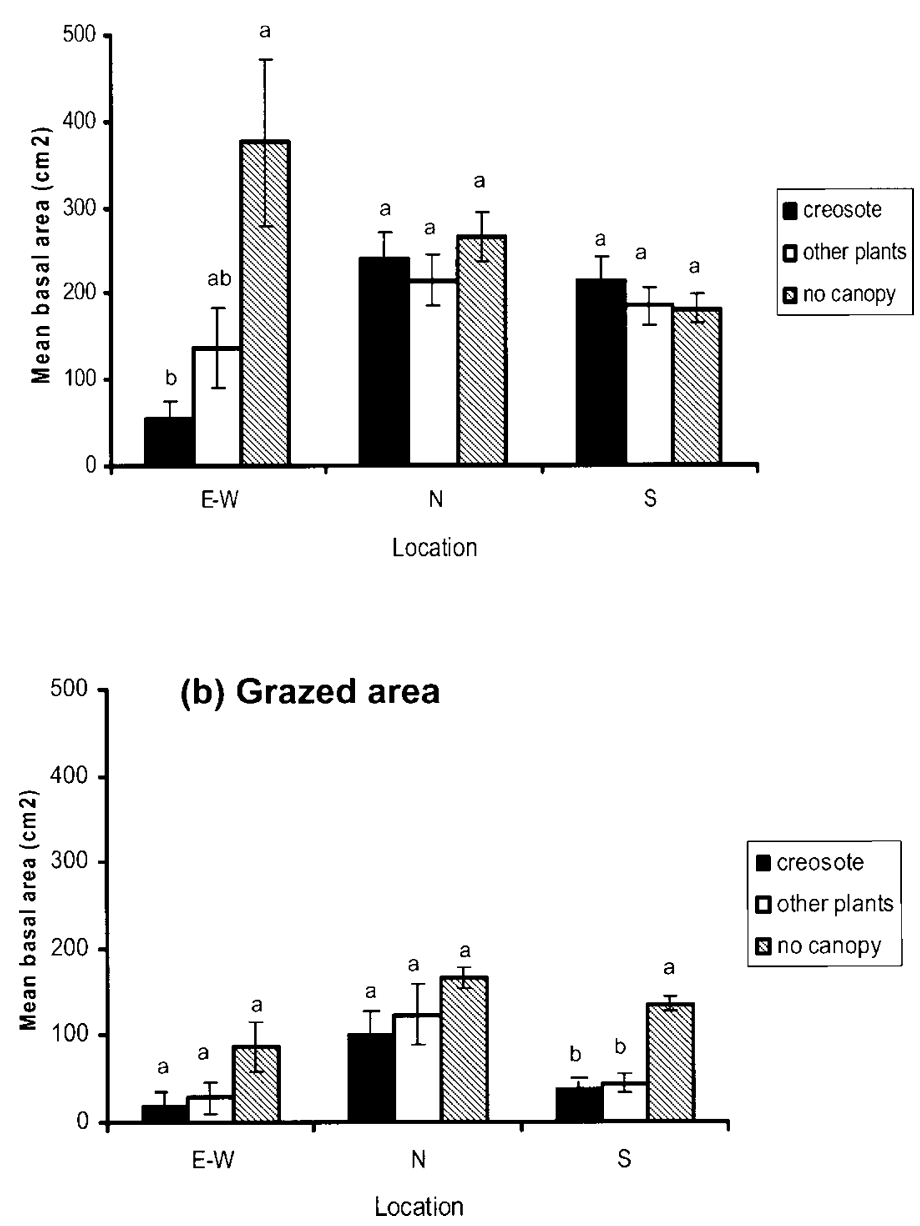

Figure 6. Average and standard deviation of basal area for 3 canopy positions and 3 aspects for black grama plants in 2 locations: a, livestock exclosure, and $\mathbf{b}$, the grazed area.

\section{ACKNOWLEDGMENTS}

Two anonymous reviewers provided helpful comments on the manuscript. Kathi Sheehan and Nellie Khalil assisted with the field sampling. Jin Yao and Barbara Nolen assisted with the spatial data layers.

\section{LITERATURE CITED}

ARCHER, S. 1989. Have Southern Texas savannas been converted to woodlands in recent history? American Naturalist 134:545-561.

ArCheR, S. 1994. Woody plant encroachment into Southwestern grasslands and savannas: rates, patterns and proximate causes. In: M. Vavra, W. A. Laycock, and R. D. Pieper [EDS.]. Ecological implications of livestock herbivory in the West. Denver, CO: Society for Range Management. p 13-69.

Archer, S., C. J. Scifres, C. Bassham, and R. Maggio. 1988. Autogenic succession in a subtropical savanna: rates, dynamics and processes in the conversion of grassland to thorn woodland. Ecological Monographs 58:111-127.

Buffington, L. C., and C. H. Herbel. 1965. Vegetational change on a semidesert grassland range from 1858 to 1963. Ecological Monographs 35: 139-164.

Ethridge, D. E., R. D. Sherwood, R. E. Sosebee, and C. H. Herbel. 1997. Economic feasibility of rangeland seeding in the arid southwest. Journal of Range Management 50:185-190. 
Fredrickson, E., K. M. Havstad, R. Estell, and P. Hyder. 1998. Perspectives on desertification: Southwestern United States. Journal of Arid Environments 39:191-207.

GaDZIA, K. L. 1979. Growth and development patterns of black grama in southern New Mexico [thesis]. Las Cruces, NM: New Mexico State University. 92 p.

Gibbens, R. P., K. M. Havstad, D. D. Billheimer, and C. H. Herbel. 1993. Creosotebush vegetation after 50 years of lagomorph exclusion. Oecologia 94:210-217.

Gibbens, R. P., R. P. McNeely, K. M. Havstad, R. F. Beck, and B. Nolen. 2005. Vegetation change in the Jornada Basin from 1858 to 1998. Journal of Arid Environments 61:651-668.

Gibbens, R. P., J. Tromble, J. T. Hennessy, and M. Cardenas. 1983. Soil movement in mesquite dunelands and former grasslands of southern New Mexico from 1933 to 1980. Journal of Range Management 36:145-148.

Gillette, D. A., And W. Chen. 2001. Particle production and aeolian transport from a "supply-limited" source area in the Chihuahuan desert, New Mexico, United States. Journal of Geophysical Research 106:5267-5278.

Grover, H. D., AND H. B. Musick. 1990. Shrubland encroachment in southern New Mexico, U.S.A.: an analysis of desertification processes in the American Southwest. Climatic Change 17:305-330.

Havstad, K. M., R. P. Gibbens, C. A. KnorR, and L. W. Murray. 1999. Long-term influences of shrub removal and lagomorph exclusion on Chihuahuan Desert vegetation dynamics. Journal of Arid Environments 42:155-166.

Herrick, J. E., K. M. Havstad, and D. P. Coffin. 1997. Rethinking remediation technologies for desertified landscapes. Journal of Soil and Water Conservation 52:220-225.

Herrick, J. E., K. M. Havstad, and A. Rango. 2006. Remediation research in the Jornada Basin: past and future. In: K. M. Havstad, W. H. Schlesinger, and L. F. Huenneke [EDS.]. Structure and function of a Chihuahuan Desert ecosystem: The Jornada Basin LTER. Oxford, UK: Oxford University Press.

LitTell, R., W. Stroup, and R. Freund, 2002. SAS ${ }^{\circledR}$ for linear models. 4th ed. Cary, NC: SAS Institute, Inc.

Minnick, T. J., And D. P. Coffin. 1999. Geographic patterns of simulated establishment of two Bouteloua species: implications for distributions of dominants and ecotones. Journal of Vegetation Science 10:343-356.

Neilson, R. P. 1986. High-resolution climatic analysis and Southwest biogeography. Science 232:27-34.

Nelson, E. 1934. The influence of precipitation and grazing upon black grama grass range. Washington, DC: US Department of Agriculture. USDA Technical Bulletin No. 409. $32 \mathrm{p}$.

Peters, D. P. C. 2002. Recruitment potential of two perennial grasses with different growth forms at a semiarid-arid ecotone. American Journal of Botany 89:1616-1623.

Peters, D. P. C., B. T. Bestelmeyer, J. E. Herrick, E. Fredrickson, H. C. Monger, and K. M. Havstad. 2006. Disentangling complex landscapes: new insights to forecasting arid and semiarid system dynamics. BioScience 56:491-501.

Rango, A., S. C. Goslee, J. E. Herrick, M. Chopping, K. M. Havstad, L. F. Huenneke, R. P. Gibiens, R. Beck, and R. McNeely. 2002. Remote sensing documentation of historic rangeland remediation treatments in southern New Mexico. Journal of Arid Environments 50:549-572.

Ricketts, T. H., K. Carney, R. A. Abell, S. Walters, E. Dinerstein, D. M. Olson, C. J. Loucks, W. Eichbaum, D. DellaSalla, K. Kavanagh, P. Hedao, and P. Hurley. 1999. Terrestrial ecoregions of North America: A conservation assessment. Washington, DC: Island Press. 508 p.

SAS ${ }^{\circledR}$ InSTITUTE. 1999. SAS/STAT ${ }^{\circledR}$ user's guide. Version 8. Cary, NC: SAS Institute, Inc. $1848 \mathrm{p}$.

Schlesinger, W. H., J. F. Reynolds, G. L. Cunningham, L. F. Huenneke, W. M. Jarrell, R. A. Virginia, and W. G. Whitford. 1990. Biological feedbacks in global desertification. Science 247:1043-1048.

Snyder, K. A., K. A. Mitchell, and J. E. Herrick. 2006. Patterns and controls of soil water in the Jornada Basin. In: K. M. Havstad, W. H. Schlesinger, and L. F. Huenneke [EDS.]. Structure and function of a Chihuahuan Desert ecosystem: The Jornada Basin LTER. Oxford, UK: Oxford University Press.

Wainwright, J. A., A. J. Parsons, W. H. Schlesinger, and A. D. Abrahams. 2002. Hydrology-vegetation interactions in areas of discontinuous flow on a semiarid bajada, southern New Mexico. Journal of Arid Environments 51: 219-258.

Warren, A., J. Holechek, and M. Cardenas. 1996. Honey mesquite influences on Chihuahuan Desert vegetation. Journal of Range Management 49:46-52.

Whisenant, S. G. 1999. Repairing damaged wildlands: A process-oriented, landscape-scale approach. Cambridge, UK: Cambridge University Press. $312 p$

York, J. C., AND W. A. Dick-PeddiE. 1969. Vegetation changes in southern New Mexico during the past 100 years. In: W. G. McGinnies, and B. J. Goldman (EDS.). Arid lands in perspective. Tucson, AZ: University of Arizona Press. p 157-166. 